\title{
GDP, Labor and Investment Towards Employment In West Java
}

\author{
Yuyus Yudistria \\ STIE Ekuitas, Kota Bandung, Jawa Barat 40124, Indonesia
}

\begin{abstract}
Absorption of worker is an important thing in the national and regional development. Worker can be become a benchmark of successful the development of the area, it means absorbing worker supports the successful of whole national development. The objective of the research is to knowhow toinfluenceGDP, laborandinvestmenttowardsemploymentin West Java? Method ofThisstudyusessecondary data from pooled datawhichis a combination of time series data andthe crosssection datain24regencies / citiesin West Java. Based on theresultsobtainedthat, GDP, wageandinvestmentget togetherinfluence significantly on absorption of worker in West Java. Thenpartially, GDPvariablehas apositiveeffect to the employment. Wage factor has asignificantnegativeeffect to the employment, while theinvestmentfactorhas apositive effectbut insignificanteffectto theemployment. This research suggests local government is expected to further encourage and push even spur economic growth, especially growth in every sector. Local governments need to overcome wages problems so that can improve the welfare of the workers without compromising the interests of employers. Investment in West Java province which has no significant effect on employment indicate that as long as these investors tend to impose a system of capital-intensive rather than labor-intensive, so that local governments should be more selective in granting licenses to investors associated with employment needs.
\end{abstract}

Keywords: Employment, wage, investment

\section{Introduction}

Economic development aims to increase the economic growth, employment opportunities, income generation, economic equality and balanced economic structure for society.Regional development as an integral part of national development areimplemented based on the principle of local autonomy and the setting of national resources which provides an opportunity for the improvement of democracy and regional performanceto improve the welfare of society that is free from corruption, collusion and nepotism. (UU Otonomi Daerah, 1999).

Employment is an important issue in national and regional development. Labor could be used as a measure of the success of development of a region, meaning that employment support the success of national development as a whole.

Based on data from the Regional Social Economic Survey in West Java in 2003 to 2007 the number had increased employment, conditions of employment from 2003 to 2007 the agricultural sector is still the most widely business field absorb workforce. In 2007, from 17.19 million people from West Java who work, 27.20 percent work in agriculture, 24.59 percent in the trade sector, 15.74 per cent in the industrial sector, 16.72 per cent in the service sector, and by 15.73 percent spread in various sectors such as finance, transport, construction and others. It appears that in terms of employment in existing sectors, agriculture, commerce, industry, and services at the most chosen people of West Java. Compared with 2006, an increase in employment in the agricultural sector and the service sector, but on the other hand a decline in employment in trade, industry and in various sectors such as finance, transport, construction, and others.

Employment not only rely on the improvement of the quantity of the amount of labor that can be absorbed by sectors of the economy, but also to be in line with the improvement of the quality of labor. Improvement of the quality synonymous with increased welfare workers. As remuneration of labor (wages) is an additional indicator that can be used to see the acceleration of employment and economic progress in the region. The level of Provincial Minimum Wage (UMP) in West Java in 2007 (West Java Governor Decree No. 561 / Kep.984-Bangsos / 2006 on UMP Jabar 2007) Rp. 516 840, - or an increase of $15.46 \%$, compared to the UMP in 2006 was only Rp. 447 654, -. The wage increase will have an impact on improving the welfare of workers and purchasing power. Purchasing power will stimulate aggregate demand and ultimately will have an impact on economic growth and sectoral. Increased sectoral growth will result in an increase in employment stimulus.

Investment is the first step of production. Investments in essence is also a step in the dynamics of economic development activities, the level of capital investment affect economic growth. In an effort to grow the economy of every country trying to create a climate that can stimulate investment. (Dumairy, 1997:132).

West Java as one of the provinces that have a high enough potential in developing various sectors. The investment climate in West Java also showed improved growth. West Java is still the main destination of foreign investment and domestic investment. Total Realization of Investment in domestic and foreign based Activity Report (LKPM) up to the reporting period from January to December of 2011 were realized by the investors in the 26 (twenty-six) Regency / City with a total investment of Rp. 48,751,176,609,700, and total employment of 396710 people, as well as the number of 767 projects LKPM project. The investment amount is greater than the year 2010 amounting to $\mathrm{Rp}$ $2,148,561,446,541$, where in 2010 a total investment of Rp. $46,602,615,163,159$.

\section{Volume 5 Issue 2, February 2016}




\section{International Journal of Science and Research (IJSR) \\ ISSN (Online): 2319-7064}

Index Copernicus Value (2013): 6.14 | Impact Factor (2014): 5.611

The purpose of this study are: to know how to influence GDP, labor and investment towards employment in West Java?

\section{Previous Work}

1. Analisis Pengaruh PDB Sektor Industri, Upah Riil, Suku Bunga Riil, Dan Jumlah Unit Usaha Terhadap Penyerapan Tenaga Kerja Pada Industri Pengolahan Sedang Dan Besar Di Indonesia Tahun 1990-2008 oleh Rezal Wicaksono

The manufacturing sector contributes significantly to GDP in Indonesia. But, in fact, employment in the manufacturing sector is relatively smaller than the agricultural sector and Wholesale, Retail, Restaurant and Hotel. The manufacturing sector is expected to absorb a lot of labor. Labor absorption is influenced by several factors, namely: GDP, wages, interest rates, and the number of business units. Effect of labor absorption is because, with the decline in interest rates will encourage employers to increase the number of its business units that will increase employment. While GDP is an indicator of economic growth, so that with increasing GDP, economic growth has also increased and employment has also increased. On wages, inversely proportional relationship, so that if wage increases, would reduce employment.

The dependent variable in this study is employment, the number of people working in DKI Jakarta which can be absorbed in the labor market at the level of the various wage levels.

1) Significant Parameter Test Individuals (statistical test $t$ ). Based on secondary data processed concluded that GDP (XI) having a positive relationship with employment. While the real wage rate (X2) and real investment (X3) negatively related to employment in Jakarta. Statistically, through the $\mathrm{t}$ test known that individually each of the independent variables GDP, the level of real wages and real investment value significantly influence the dependent variable on the degree of confidence by 1 percent.

2) Simultaneous Test Significance (statistical test F) From the calculation, that the value of Prob (F-statistic) is equal to 0.000088 . It can be concluded that the independent variables jointly affect the dependent variable.

3) The coefficient of determination (R2). Based on the results of the regression is known that the coefficient of determination R2 of 0.84 . That is, the contribution of variation of independent variables in explaining the variation of the dependent variable by 84 percent, while 16 percent is explained by other variables outside the model.

\section{Methods}

\section{Analysis Method}

In this study used regression analysis. According to Agus Widarjono (2005), regression analysis explains the relationship between the dependent variable and the independent variables are strongly associated with relationships that are not statistically or passive relationship which is also called random links. Regression also showed one-way relationship of the independent variables to the dependent variable. The magnitude of the effect of this variable can be predicted by the amount indicated by the regression coefficient.

This Study uses pooled data, which is a combination of time series of data and cross section data. Selection of panel data in this study is very relevant to the goals of research to estimate the 24 regencies / cities in West Java during the period 2005 to 2009 .

\section{Econometric Model}

a model to look at the factors that affect the absorption tanaga Bring sectoral work in the West. This study uses a recursive equation because there is no reciprocal relationship between the endogenous variables in the model. The model in this study showed one-way relationship. The model used to refer research "Absorption of Labor in the city" by: Dimas danNunikWoyanti (2009) are as follows:

\author{
$\mathrm{LnTK}_{\mathrm{it}}=\beta 0+\beta \mathrm{iLnPDRB}_{\mathrm{it}}+\beta \mathrm{iLnUpah}_{\mathrm{it}}+\beta \mathrm{iLnINV}_{\mathrm{it}}+\mu$ \\ Where's \\ $\beta 0$ : intercept \\ $\beta \mathrm{i}$ : regression coefficients were estimated \\ TK: Absorption of Labor (people) \\ GDP: GDP (USD Million) \\ WAGES: Real Wage (RP) \\ INV: Investment Real (RP Million) \\ $\mu$ : Factor Disorders \\ Ln: Natural logarithm
}

\section{Criteria Econometrics}

Tests with these criteria help determine whether an estimate has the properties required. If the assumptions are applied econometric techniques to estimate the parameters are not met, then the estimates are considered not to have the required properties. Criteria Econometrics For Data Analysis Panel is as follows:

1) Descriptive Statistics (JarqueBera) for normality test

2) Test multikolenieritas

3) Test Hausman (random versus fixed)

4) From the test results will be obtained Hausman test whether the choice of using a fixed effect or random effect

5) Test LM: theHeteroskidastity between groups of individuals (crossection).

6) Test Symptoms Heteroskidastity (Breusch-PaganGodfrey)

\section{Criteria Statistics}

- The t-statistics test

- F-Statistics test

- Test of determination (R2)

\section{Result}

Workforce development, GDP, wages and Investment Workforce development, Gross Domestic Product (GDP), wages and aggregate investment in West Java showed varied developments. Discussion on the development of employment, GDP, labor and investment are further divided into two topics, namely: 1). discussion of a general overview of the development of employment, GDP, wages and

\section{Volume 5 Issue 2, February 2016}




\section{International Journal of Science and Research (IJSR) \\ ISSN (Online): 2319-7064 \\ Index Copernicus Value (2013): 6.14 | Impact Factor (2014): 5.611}

investment in West Java; and 2). Conditions of employment growth, GDP, wages and investment in the District and the City.

\section{Manpower Absorption development, GDP, Wage Rates and Investment in West Java \\ Conditions of employment development in West Java province Shows fluctuated increase, employment was highest in 2008 which is about 18,357,579 inhabitants, but back in 2009 a decline of about $18,100,542$ inhabitants or decreased approximately $1.4 \%$, increase significant occurred in 2007, where in 2007 there were several districts / cities that conduct regional divisions so that the increase in employment.}

The development of employment in every province of West Java. Seen from the year has increased. Employment are more prevalent in counties and cities show that the Bogor district in 2005 approximately 1.4 million workers absorbed then increased in 2009 to 1.8 million, this figure proves that the Bogor Regency is better for labor absorption than in Bandung District which annually has decreased. While the city of Sukabumi and Cirebon city is a city very drastic reduction in its workforce in 2009. This is because many businesses out of business, resulting from the economic crisis and high prices of raw materials. Cirebon as the city of rattan and teak, which once felt the impact of the economic crisis. Soaring prices resulted in many businesses that no longer carry on business

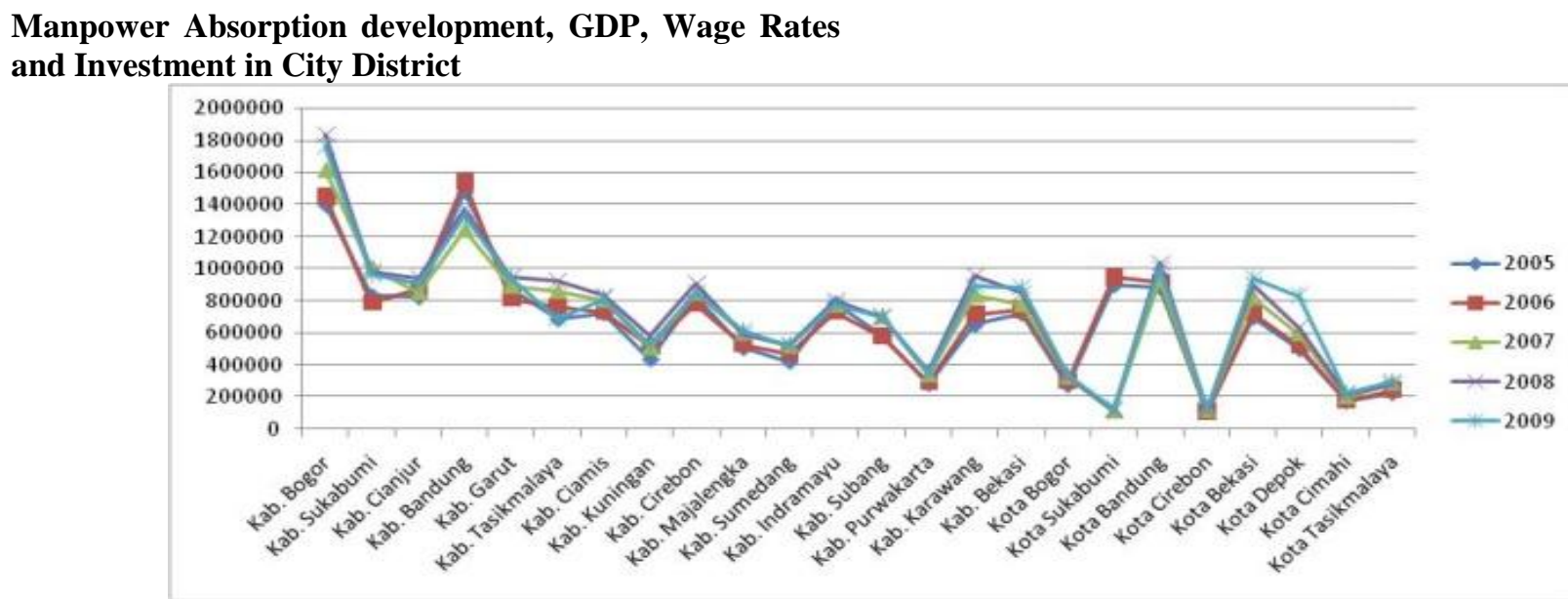

Graph Development of Manpower Absorption Conditions in District / City of West Java Province Year 2005 - 2009

Bekasi District is one district that has the highest value of GDP compared to other districts and the city which is about Rp. 51 trillion. Additionally GDP Bekasi district from 2005 until 2009 continued to increase as compared to other cities and counties. Even in the city of Bekasi itself PDRD still far below the value of the Bekasi district. The high level of GDP in Bekasi one of which is the presence of an industrial area, where the contribution of the industrial sector alone nearly $80 \%$ of the Bekasi district PDRB.Ini prove more potent, many things can be developed both natural resources and human resources. While the city of Sukabumi is a district that has the value of GDP is smaller than other cities and districts. From year to year GDP kotaSukabumi tend to be stable. Sukabumi is an area that is not so productive.

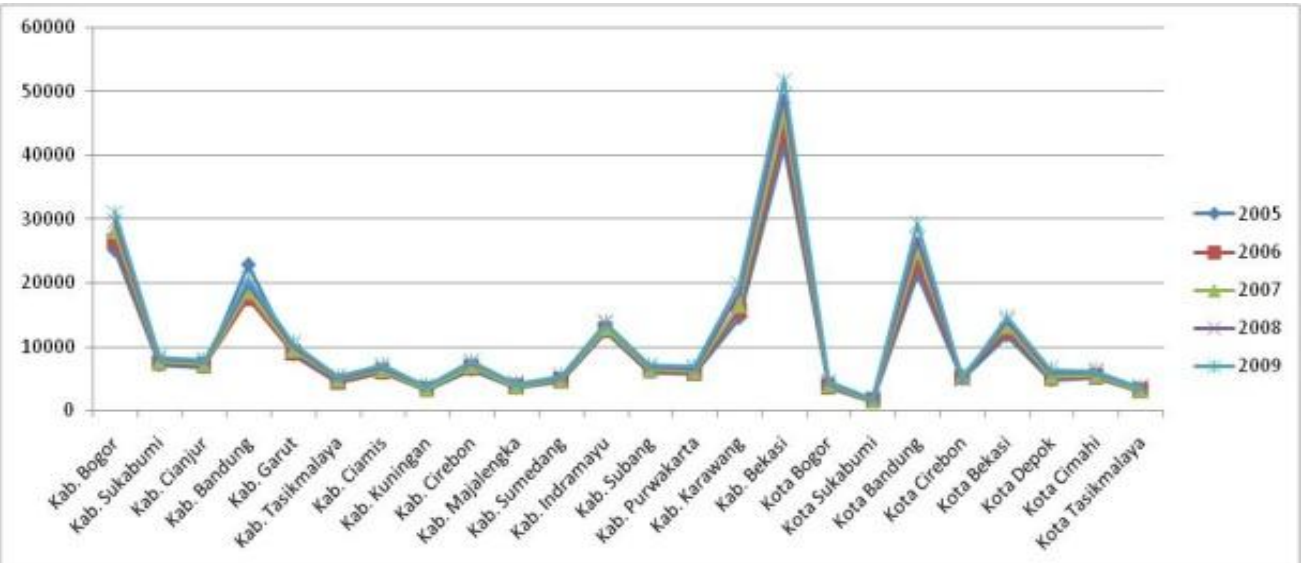

Graph Development of Gross Regional Domestic Product in the Regency / City of West Java Province Year 2005 - 2009

The minimum wage in the district / city (UMK) showed that Bekasi district UMKnya higher than other cities and districts. The condition is caused due to the cost of living in the city / district Bekasi are quite high, and the high cost of basic needs that exist, the condition is also one of them influenced by the geographical conditions in which the Bekasi district adjacent to the Capital, While the town of Tasikmalaya and Sukabumi is UMKnya cities and counties are low compared to cities and districts dipropinsi West 


\section{International Journal of Science and Research (IJSR) \\ ISSN (Online): 2319-7064}

Index Copernicus Value (2013): 6.14 | Impact Factor (2014): 5.611

Java. Tasikmalaya city, a small town that average citizens

work as labor in the company both private and government.

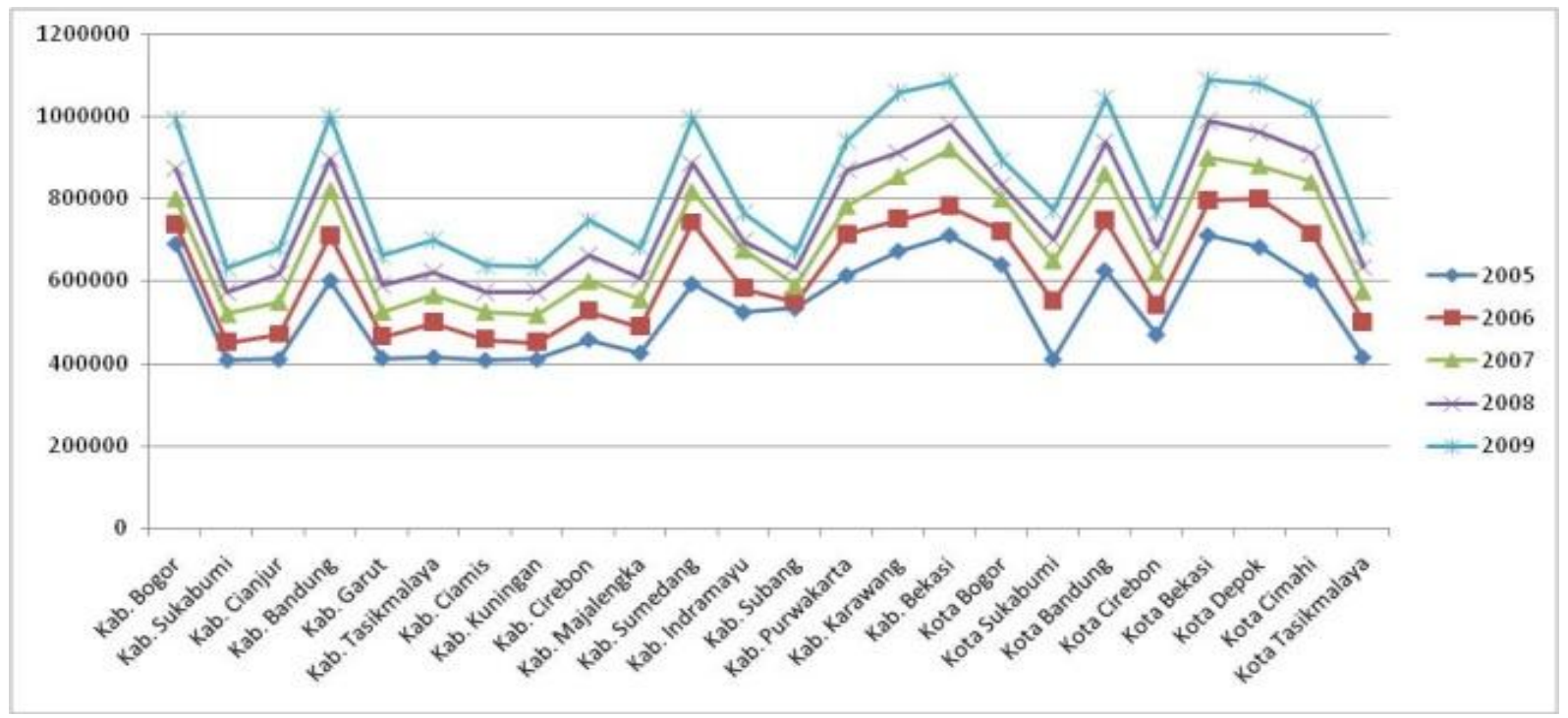

Graph Wage Labor (Minimum Wage District / City) In District / City West Java Province Year 2005 - 2009

Bekasi district in terms of investment is very significant growth, despite a decline in 2005. However, in 2009 an increase of about $50 \%$. Under these conditions proves the confidence level of investors to develop business in Bekasi district quite well. Unlike the Garut district, county / city of Tasikmalaya, Ciamis regency and district brass for development of investment from 2005 to 2009 did not develop investment. This is due to the lack of products / services with the potential to be developed, so that investors or businesses are less interested in developing business in the area.

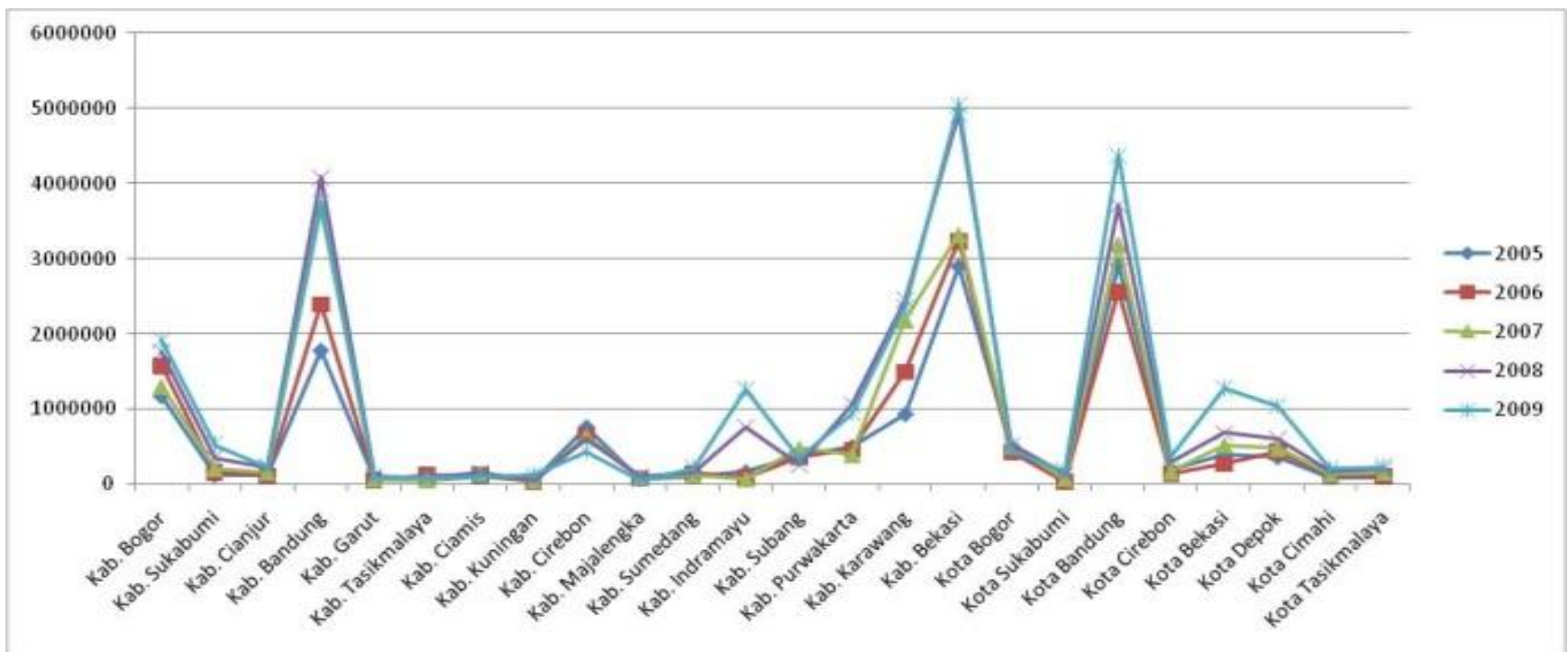

Graph Investment Based Commercial Bank Loan and BPR in the Regency / City in West Java Year 2005 - 2009

Econometric Analysis of Effect of GDP, Level of Wages and Labor Absorption Against Investment in West Java Early indications in the hypothesis suspected the influence of GDP, the level of labor and investment towards on employment. Wherein the variables GDP, the level of labor and investments thought to have an impact on employment. Gross Regional Domestic Product and investment is thought to have a positive impact on employment, and wages are expected to have a negative effect on employment. This phenomenon can be identified from the existing symptoms, which affect GDP at most on employment. Effect of GDP, the level of labor and investments on employment are tested in econometric analysis, using panel data. From the data processing generated output data panel with four different methods, ie using a model Hausman test for testing whether using a fixed effect or randomeffect, wherein the method used is gradually falsifies the previous method.

\section{Descriptive Statistics}

The highest mean value is variable investment of Rp. 811 billion while the lowest mean value is a GDP of Rp. 11 Trillion. If seen from the normality test normally distributed variables only wage with a probability value of the JarqueBera test of 0.0799 , which means greater than the significance level of 5 percent, or 0.05 , while the other three variables, namely GDP and workforce investments are not 


\section{International Journal of Science and Research (IJSR) \\ ISSN (Online): 2319-7064 \\ Index Copernicus Value (2013): 6.14 | Impact Factor (2014): 5.611}

distributed normal with a probability value of the test Jarque-Bera smaller than the level of significance of any $(10 \%, 5 \%$ and $1 \%)$ this is caused by the value of skewness is far from zero (normal distribution skewness in numbers ranging from zero) and the value of kurtosis which is far from the number three (normal distribution kurtosis value should be close to the number three).

Descriptive Statistics Table

\begin{tabular}{|l|c|c|c|c|}
\hline & Investment & GDP & Labor & WAGES \\
\hline Mean & 811612.2 & 11045.87 & 718800.8 & 691903.8 \\
\hline Median & 274514.0 & 6732.000 & 742586.0 & 676000.0 \\
\hline Maximum & 5047450. & 51790.00 & 1955825. & 1089000. \\
\hline Minimum & 36632.00 & 1421.000 & 103077.0 & 408000.0 \\
\hline Std. Dev. & 1161331. & 10580.99 & 396001.7 & 177645.4 \\
\hline Skewness & 1.978161 & 1.974800 & 0.910409 & 0.384748 \\
\hline Kurtosis & 6.059963 & 6.572824 & 4.396508 & 2.346464 \\
\hline Jarque-Bera & 124.0370 & 140.6402 & 26.10865 & 5.053697 \\
\hline Probability & $\mathbf{0 . 0 0 0 0 0 0}$ & $\mathbf{0 . 0 0 0 0 0 0}$ & $\mathbf{0 . 0 0 0 0 0 2}$ & $\mathbf{0 . 0 7 9 9 1 0}$ \\
\hline Sum & 96581852 & 1314458. & 85537294 & 82336547 \\
\hline Sum Sq. Dev. & $1.59 \mathrm{E}+14$ & $1.32 \mathrm{E}+10$ & $1.85 \mathrm{E}+13$ & $3.72 \mathrm{E}+12$ \\
\hline Observations & 119 & 119 & 119 & 119 \\
\hline
\end{tabular}

\section{Symptoms Test Multicollinearity}

Testing symptoms multikolinieritas can be done by looking at the correlation between the independent variables, and according to Gujarati (2006) can be used varianve-inflating factors (VIF), if VIF is more than 10 , then allegedly there multikolinearitas high and vice versa if VIF is less than 10 , then there is no problem multicolinearity in the model. VIF shown by all the variables GDP, wages and investment is at a value below 10 (VIF <10) indicating that the structural economic transformation variables no problems for multikolineratitas.

Table: Symptoms Multicollinearity

\begin{tabular}{|c|c|c|c|c|c|}
\hline No & $\begin{array}{c}\text { Free } \\
\text { Variable }\end{array}$ & Tolerance & VIF & Kriteria & Keputusan \\
\hline 1 & GDP & 0.207 & 4.832 & VIF $<10$ & $\begin{array}{c}\text { Non } \\
\text { multikolinearitas }\end{array}$ \\
\hline 2 & Labor & 0.667 & 1.499 & $\mathrm{VIF}<10$ & $\begin{array}{c}\text { Non } \\
\text { multikolinearitas }\end{array}$ \\
\hline 3 & Investment & 0.180 & 5.571 & $\mathrm{VIF}<10$ & $\begin{array}{c}\text { Non } \\
\text { multikolinearitas }\end{array}$ \\
\hline
\end{tabular}

Source: Estimation Results

\section{Hausman test Test in Panel Data}

In examining the data panel will require testing whether using a fixed effect or randomeffect, this test is usually used Hausman test. The criteria is if the probability of chi-square is greater than the significance of $10 \%, 5 \%$ and $1 \%$, it is advisable to use a random effect, whereas if the probability of chi-square is smaller than the significance level of a good $10 \%, 5 \%$ and $1 \%$, it is advisable to use a fixed effect. Hausman test calculation results can be seen in the table below:

Table: Correlated Random Effects - Hausman Test

\begin{tabular}{|c|c|c|c|}
\hline \multicolumn{4}{|c|}{ Correlated Random Effects - Hausman Test } \\
\hline \multicolumn{4}{|c|}{ Pool: POOL01 } \\
\hline Test cross-section random effects \\
\hline Test Summary & Chi-Sq. Statistic & Chi-Sq. d.f. & Prob. \\
\hline Cross-section random & 9.749963 & 3 & 0.0208 \\
\hline
\end{tabular}

Testing Results Hausman test showed that the probability of the chi-square value significantly to the value of 0.0208 , which means less than the significance level of $5 \%$, or 0.05 , thus the test data using a fixed effect panel.

\section{Test Results Panel Data Estimation}

$\mathrm{LnTK}_{\text {it }}=8.409+0.626 \mathrm{LnPDRB}_{\text {it }}-0.126 \mathrm{LnUpah}_{\text {it }}+$

$0.075 \mathrm{LnINV}_{\text {it }}+\mu$

T-stat : (8.677) (5.464) (-1.703) (0.713)

F-stat : 14.592

Adjusted R-squared : 0.749

Based on the results of the processing of data regression showed that the GDP variable is significant at the 5\% level and even at the $1 \%$ level because the t-stat probability value of less than $1 \%$, then the variable salary is only significant at $10 \%$ or 0.1 but not at $5 \%$ with a probability value of 0.0919 . Variables declared investment is not significant at any level $(1 \%, 5 \%$ and $10 \%)$. Then the value of R2 adjus by $74907 \%$ and indicated a significant probability of f-stat value smaller than the $1 \%$ level, which means either a third variable, GDP, wages and investment simultaneously or simultaneously influence the change in employment.

\section{Autocorrelation Test Results and Heteroskedasticity}

Based on test results Autocorrelation and Heteroskedasticity generated as follows:

\section{A. Autocorrelation LM Test}

Table: Breusch-Godfrey Serial Correlation LM Test

\begin{tabular}{|c|c|c|c|}
\hline \multicolumn{3}{|c|}{ Breusch-Godfrey Serial Correlation LM Test: } & \\
\hline F-statistic & 1.907274 & Prob. F(1,114) & 0.17 \\
\hline Obs*R-squared & 1.97641 & Prob. Chi-Square (1) & 0.1598 \\
\hline
\end{tabular}

Based on the table above can be seen that the probability of the chi-square value of Obs * R-squared of 0.1598 which is greater than the significance level $(10 \%, 5 \%$ and $1 \%)$ so that it can be concluded that there is no autocorrelation.

\section{B. Heteroskedasticity Test}

Table: Heteroskedasticity Test: Breusch-Pagan-Godfrey

\begin{tabular}{|c|c|c|c|}
\hline \multicolumn{4}{|c|}{ Heteroskedasticity Test: Breusch-Pagan-Godfrey } \\
\hline F-statistic & 1.435545 & Prob. F(3,115) & 0.2361 \\
\hline Obs*R-squared & 4.295568 & Prob. Chi-square(3) & 0.2313 \\
\hline Scaled explained SS & 7.834701 & Prob. Chi-Square(3) & 0.0496 \\
\hline
\end{tabular}

From the table above it can be seen that the probability of the chi-square value of $\mathrm{Obs} * \mathrm{R}$-squared of 0.2313 , which means greater than the significance level $(10 \%, 5 \%$ and $1 \%)$ so that it can be concluded that there is no heterokedasticity.

\section{Criteria Test Results Statistics}

Test result statistical criterion is the size of the model to be used in the estimation, so it must fulfill the criteria t test, $F$ test and coefficient of determination.

\section{The T-test}

In the equation panel data with cross-section need to be tested for the variable partial relationship GDP, labor and

\section{Volume 5 Issue 2, February 2016}




\section{International Journal of Science and Research (IJSR) \\ ISSN (Online): 2319-7064}

Index Copernicus Value (2013): 6.14 | Impact Factor (2014): 5.611

investment on employment, confidence level of $95 \%$ and $90 \%$, or $\mathrm{a}=0,05$ and $\mathrm{a}=0,1$, The criteria used is the ratio betweent $_{\text {tabel }}$ Witht $_{\text {hitung }}$ the following provisions:

1) $t_{\text {hitung }}>t_{\text {tabel }}$, it is in the area of rejection, which means that between independent variables and the dependent variable correlation

2) $t_{\text {hitung }}<t_{\text {tabel }}$, it is at the reception area, which means that between independent variables and the dependent variable there is no correlation

Value oft tabel obtained from a table $\mathrm{t}$ inverse in $\mathrm{a} / 2$, and with a degree of confidence $\mathrm{df}=118($ or $\mathrm{n}-1)$, thent $\mathrm{tabel}(0,05)=1,980$ andt $_{\text {tabel }(0,01)}=1.657$.

Table Effect Variables Partial Absorption against Labor in West Java

\begin{tabular}{|c|c|c|c|c|}
\hline \multirow{2}{*}{ No } & \multirow{2}{*}{ Variable } & Kriteria & \multirow{2}{*}{ Result } & \multirow{2}{*}{ Description } \\
\cline { 3 - 3 } & & $\mathbf{T}_{\text {hitung }}><\mathbf{T}_{\text {tabel }}$ & & \\
\hline 1 & GDP & $\mathbf{5 . 4 6 4}>\mathbf{1 . 9 8 0}$ & Ho Rejected & Significant \\
\hline 2 & WAGES & $\mathbf{- 1 . 7 0 3}>\mathbf{1 . 6 5 7}$ & Ho Rejected & Significant \\
\hline 3 & Investments & $\mathbf{0 . 7 1 3}<\mathbf{1 . 6 5 7}$ & Ho Rejected & No Significant \\
\hline
\end{tabular}

Sources: Estimation Results

Referring to the above criteria for each independent variable which meett $_{\text {hitung }}>t_{\text {tabel }}$, so it can be inferred the existence of a significant relationship between GDP and wages of workers with employment. While variable investments have no significant relationship with employment which is smaller than the significance of $10 \%, 5 \%$ and $1 \%$.

\section{The F-Test}

Estimates on the $\mathrm{F}$ test statistic, a value is examine the relationship GDP, labor and investment with employment. F test performed at $90 \%$ confidence level and a $95 \%$ or a $=$ 0.05 and 0.01 . The criteria used is the ratio between $f_{\text {tabel }}$ withf $_{\text {hitung }}$ the following provisions:

1) $f_{\text {hitung }}>f_{\text {tabel }}$, it is in the area of rejection, which means that between independent variables and the dependent variable correlation

2) $f_{\text {hitung }}<f_{\text {tabel }}$, it is at the reception area, which means that between independent variables and the dependent variable there is no correlation

\section{Conclution}

Based on the results of the regression of the three independent variables using data panel regression model, it can be concluded that based on primary regression independent variables, namely GDP, wages and investment jointly significant influence on employment in West Java. Partially, GDP variable significant influence on the degree 5 percent wage levels significant influence on the degree of 10 percent and investment is not significant effect on the degree of 10 percent, 5 percent and 1 percent, on employment in West Java. The coefficient value shows that when GDP increases by 1 percent, the employment increased by 0.626 percent. If the wage increase of 1 percent will lower the employment of 0.126 percent. If investment rose by 1 percent, the employment of 0.075 percent.

\section{Future Scope}

Based on the discussion and conclusions can be submitted several suggestions to overcome the problems of employment, especially in West Java:

1) GDP has a positive and significant impact on employment in West Java province, the local government is expected to further encourage and spur further economic growth, especially the growth in each sector.

2) The local government needs to address the issue of wages so as to improve the welfare of workers without compromising the interests of employers.

3) Investment in West Java has no significant effect on employment indicate that during these investors tend to invest capital intensive not labor intensive padainvestasi. Based on this phenomenon local authorities should be more selective in giving permission for investors associated with employment needs.

\section{References}

[1] Afrida, BR. 2003. Ekonomi Sumber Daya Manusia, Ghalia Indonesia, Jakarta

[2] Arief, Sritua 1998, Teori dan Kebijaksanaan Pembangunan, PT. Pustaka Cidesindo, Jakarta

[3] Aris Ananta. 1990. EkonomiSumberDayaManusia. Jakarta: LembagaDemografiUniversitas Indonesia FakultasEkonomi. Arsyad Lincolin (1999), Ekonomi Pembangunan, Bagian Penerbitan STIE - YKPN, Yogyakarta

[4] Asosiasi Pengusaha Indonesia (APINDO), Rekapitulasi UMP Dan UMK 2006 s/d 2009.

[5] Badan Pusat Statistik (BPS), Jabar Dalam Angka, Edisi 2006-2009, Jawa Barat

[6] Badan Perencanaan Daerah (Bapeda), Suseda Edisi Tahun 2006-2009, Jawa Barat

[7] Budi Satria. 2005. Model Penyerapan Tenaga KerjaBerdasarkanLapangan Usaha Di Propinsi Lampung. Tesis Magister PerencanaandanKebijakanPublikFE-UI

[8] Chenery, Syrquin. 1975. Pattern of Development 19501970. London: Oxford University Press.

[9] Dumairy, 1999, Perekonomian Indonesia,Erlangga, Jakarta.

[10] Dickens WT and LF Katz (1987) Inter-Industry Wage Differences and Industry Characteristics Dalam K Lang dan JS Leonard (eds) Unemployment and The Structure of Labor Markets Basil Blackwell Inc New York

[11] Dimas danNunikWoyanti 2009. Penyerapan Tenaga Kerja di DKI, JurnalBisnisdanEkonomi (JBE) Vol. 16 No. 01 MaretTahun 2009

[12] Ehrenberg dan RS Smith. 1998. Modern Labor Economic, Theory and Public Policy Illiunis, Fresment and Company

[13] Gujarati Damodar N. 2012. Basic Econometrics, $5^{\text {th }}$ editions. Prentice Hall Inc, New Jersey. Terjemahan. SalembaEmpat Jakarta

[14] Hartono, J. (2004). Teori Portofolio dan Analisis Investasi. BPFE UGM, Yogyakarta.

[15] Hauser, Philip M. 1974. "The Measurement of Labour Utilization", Malayan Economic Review,1(April): 1 25

Volume 5 Issue 2, February 2016

www.ijsr.net 


\section{International Journal of Science and Research (IJSR) \\ ISSN (Online): 2319-7064}

Index Copernicus Value (2013): 6.14 | Impact Factor (2014): 5.611

[16] Hotchkinsdan Kauffman. 2002. The Economic Of Labor Market, Dryden Pres and Division of Harcourt College Publishers.

[17] Ignatius RohanaSitanggang, danNachrowiDjalal. 2003.PengaruhStrukturEkonomiPadaPenyerapan

Tenaga KerjaSektoral:AnalisisDemometrik di 30 PropinsiPada 9 Sektor Di Indonesia Jakarta: JurnalEkonomi Dan Pembangunan Indonesia (2003: 10-20)

[18] Intriligator MD.1978. Econometric Models: Tecniques and Aplications. Pretice- Hall Inc. New Jersey.

[19] Kusumosuwidho, Sisdjiatmo. 1981. Angkatan Kerja dalam Dasar-Dasar Dermograp. Lembaga Dermograp Fakultas Ekonomi Universitas Indonesia, Jakarta

[20] Moore JR. Principles of oral surgery.2nd Ed. Portsmouth: Manchester University Press, 1983: 22737.

[21] Payaman, Simanjuntak, 2001, Pengantar Ekonomi Sumber Daya Manusia, LPFEUI, Jakarta.

[22] Pratiwi, Fajar. 2005. "Faktor-faktor yang Mempengaruhi Investasi Swasta Domestik di Propinsi Jawa Barat 1975-2003". UGM. Yogyakarta.

[23] Rosyidi, Suherman.2000. Pengantar Ilmu Ekonomi. Jakarta:Erlangga

[24] Rezal Wicaksono 2001 Analisis Pengaruh PDB Sektor Industri, Upah Riil, Suku Bunga Riil, Dan Jumlah Unit Usaha Terhadap Penyerapan Tenaga Kerja Pada Industri Pengolahan Sedang Dan Besar Di Indonesia Tahun 1990-2008

[25] Samuelson, Paul A. dan William D. Nordhaus, 2004. IlmuMakroekonomi. EdisiKetujuhbelas. Jakarta: PT. Media Global Edukasi

[26] SadonoSukirno, 2006, Ekonomi Pembangunan Proses masalahdanDasarKebijakan, cetakanketiga, PenerbitKencana, Jakarta.

[27] Semeru, 2007. DampakKebijakanUpah Minimum terhadap Tingkat UpahdanPenyerapan Tenaga Kerja di Daerah Perkotaan Indonesia. LembagaPenelitianSemerubekerjasamadengan USAID/PEG.

[28] Sulistyaningsih, E. 2001. Dampak Perubahan Struktur Ekonomi pada Struktur Kebutuhan Kualitas Tenagakerja di Indonesia, 1980-1990; Pendekatan Input-Output.DisertasiDoktor, Program Pascasarjana, InstitutPertanian Bogor, Bogor.

[29] Suroto. 1992. Strategi pembangunan dan perencanaan kesempatan kerja. Yogyakarta: Gadjah Mada University Press.

[30] Suparmoko. 1992. Keuangan Negara dalamTeoridanPraktek. EdisiKeempat. Yohyakarta : BPFE-UGM

[31] Suryati, Maria Ni Made. 2000. "PengaruhInvestasiterhadapPenyerapantenagaKerja di Propinsi Bali".UniversitasUdayana.Denpasar.

[32] Tambunan, Tulus. 2001. Perekonomian Indonesia : Teori dan Temuan Empiris. Jakarta: Ghalia Indonesia

[33] Triyono Widodo, Suseno Hg 2000. Indikator Ekonomi, Dasar Perhitungan Perekonomian Indonesia, PenerbitKanisius.

[34] Todaro, Michael, 2001, Pembangunan Ekonomi Dania Ketiga, Erlangga, Jakarta.
[35] 2003. Pembangunan Ekonomi Di DuniaKetiga. Alih Bahasa: AminuddindanDrs.Mursid. Jakarta: Ghalia Indonesia

\section{Author Profile}

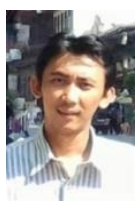

Yudistira, Yuyus was born in Subang at 13th April1978. Master Degree in Applied Economics: University of Padjadjaran (UNPAD), Bandung, Indonesia.Head of The Centre for Research and Community Services: EKUITAS School of Economics, Bandung, Indonesia. Researcher: The Research Center, Faculty of Economics, University of Pasundan, Bandung, Indonesia. Senior Researcher: The Laboratory of Management, Faculty of Economics, University of Padjadjaran, Bandung, Indonesia. Senior Researcher: The Economic Development AndRiset Institute (EDRI), Indonesia. Lecturer (Microeconomics, Macroeconomic, Economic Development, Economic Planning, and Indonesian Economy): EKUITAS School of Economics, Bandung, Indonesia. Head of The Department of Publications and Communications: The Indonesian Economists Association (ISEI), West Java, Indonesia 